\title{
Evaluation of Health Risk Concerns of Trace Metals in Borehole Water Proximal to Dumpsites in Benin City, Nigeria
}

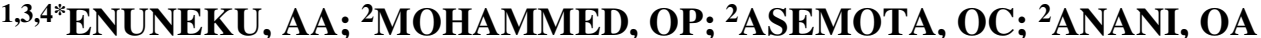

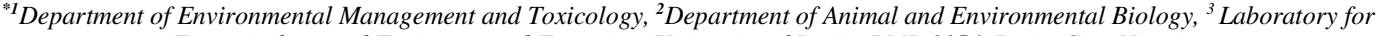 \\ Ecotoxicology and Environmental Forensics, University of Benin, PMB 1154, Benin City, Nigeria. \\ ${ }^{4}$ Laboratory of Toxicology, Graduate School of Veterinary Medicine, Hokkaido University, Kita 18, Nishi 9, Kita-ku, Sapporo 060-0818, \\ Japan. \\ *Corresponding author Email: alex.enuneku@ uniben.edu,Phone +2348030773314
}

\begin{abstract}
The objectives of this study were to evaluate the health risk concern of some trace metals in selected borehole drinking water proximal to open dumpsites in Benin City. Borehole water samples were collected and analysed for trace metals using standard methods. Health risk and pollution indices were used to characterise the trace metals. The average daily dosage (ADD) results showed low concentrations of the trace metals in the various borehole sites. Oluku 1 had $\mathrm{Mn}(0.04), \mathrm{Zn}(0.11)$ and $\mathrm{Cu}(0.01)$. Oluku $2 \mathrm{had} \mathrm{Mn}(0.43), \mathrm{Zn}(0.18)$ and $\mathrm{Cu}(0.01)$ while Ikueniro 1 had $\mathrm{Mn}(0.05)$, $\mathrm{Zn}(0.17)$ and $\mathrm{Cu}(0.01)$ and Ikueniro 2 had $\mathrm{Mn}(0.04), \mathrm{Zn}(0.15)$ and $\mathrm{Cu}(0.01)$. The hazard quotient (HQs) and hazard index (HI) values were $<1$. The results of the Metal Pollution Index (MPI) revealed the values of Oluku 1 (4.6E-06), Oluku 2 (1.0E-04), Ikueniro 1 (1.4-05) and Ikueniro 2 (5.6E-06). The classification of the water were within class 0 and 1. The findings of this study have revealed that the trace metal contents found in the boreholes waters were within the safe limits as referenced. On this premise, the borehole waters were recommended safe for consumption without any health risk impact, consequent of no evidence of pollution.
\end{abstract}

\section{DOI: https://dx.doi.org/10.4314/jasem.v22i9.10}

Copyright: Copyright $\left({ }_{0} 2018\right.$ Enuneku et al. This is an open access article distributed under the Creative Commons Attribution License (CCL), which permits unrestricted use, distribution, and reproduction in any medium, provided the original work is properly cited.

Dates: Received: 09 January 2018; Revised: 10 August 2018; Accepted: 15 August 2018

Keywords: Health Risk; Trace Metals; Borehole Water; Dumpsites

Colossal population growth, industrial boom and urban-rural developments in Nigeria, have great toll on the level of environmental deterioration. The rate of abstracting ground water in Nigeria has become a tenable way to get water of good quality. Easy access to this form of water has also led to the proliferation of Boreholes and manholes in Nigeria. Borehole serves as the most important source of drinking water in Nigeria and provides a tangible $50 \%$ of potable water around the globe (Ukpong and Okon, 2013; Musa et al., 2013; Musa and Ahanonu, 2013). This can be attributed to the level of natural self-purification capacity it has found to possess (Adefemi, 2013).

However, borehole can be contaminated via soil erosion from underground leachate seepage from contaminated dumpsites and the leaching of chemicals from human activities. The degree of this contaminations can be as a results of the precipitation pattern, depth of the water table, rate of percolation, and structures of the top soil such as textural properties (Adegbola and Adewoye, 2012; Musa and Ahanonu, 2013). The health risk from the consumption of trace metals from borehole water have been documented by several researchers (Idris et al., 2013; Kelepertzis 2014; Izah et al. 2016); Adeniyi et al., 2014; Soyingbe et al., 2014). The objectives of this study were to evaluate the health risk concern of some trace metals in selected borehole water and to assess the pollution status.

\section{MATERIALS AND METHODS}

Study Area and Sampling Stations: Oluku: This is a community with a very small population in Edo State, Nigeria. Towns near Oluku include Utekon, Iguosa, Iyowa and Ora. The closest major cities include; Benin, Owo, Akure and Warri.

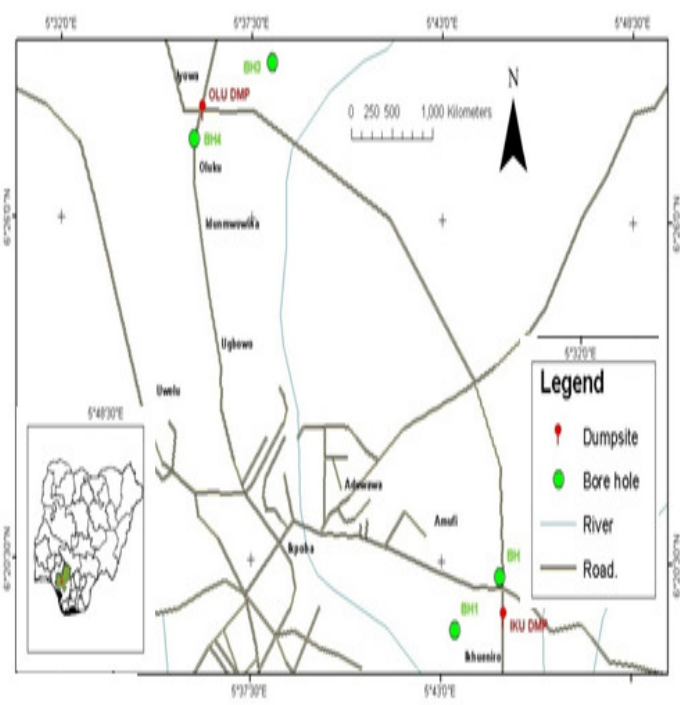

Fig 1: Map showing the sampling locations 
Ikhueniro: This area is being gradually transformed from a rural settle into an urban area. Hotels and industries are some of the proof of this transformation. These areas were chosen because of one of the main anthropogenic activities therein and large open dumpsites. The sampling locations lie between latitude $60.27^{\prime} 48 \mathrm{~N}$ and longitude 5053'5E (Fig. 1).

Geology: The geological formations are fundamentally of alluvial basins and basement multifaceted rocks (Ija and Antai, 2003). The consequence of these rock foundations is that they permit penetrability of liquids (Achudume, 2009). Their soils are gotten from sand stones and shale, and are of very recent deposits that are extremely vulnerable to washing of the topmost layer, therefore may lose their lushness in due time.

Climate: The study areas are located within the tropics, which is marked by two prominent seasons; humid tropical wet and dry seasons governed by rainfall. The wet season which has a high amount of rainfall usually spans from April to October with high humidity and low atmospheric temperature and occasional precipitation in the dry season (November to March). Annual rainfall averages $2800 \mathrm{~mm}$ with temperature varying between $23^{\circ} \mathrm{C}$ and $37^{\circ} \mathrm{C}$ in the afternoon and dropping to between $18{ }^{\circ} \mathrm{C}$ and $22^{\circ} \mathrm{C}$ at night.

Vegetation: It is composed of the rainforest type, which consists of grasses (elephant grass and guinea grass), shrubs and trees (mango, cashew, pawpaw and guava).

Sampling periodicity/ Sample collection: Water samples were collected from four boreholes, two from Oluku dumpsite vicinity and the other two from Ikueniro dumpsite vicinity, and they are represented as Oluku 1, Oluku 2, Ikueniro 1 and Ikueniro 2. Samples were collected monthly from September 2015 to February 2016. Borehole water was collected into a well rinsed $100 \mathrm{ml}$ sample container by filling the container slowly to avoid turbulence and air bubbles. Sample containers were labelled appropriately.
Determination of Heavy metals: Heavy metals were determined after digestion of the solution of the samples. Digestion was carried out by taking $10 \mathrm{ml}$ of the sample and adding $4 \mathrm{ml}$ Perchloric acid, $20 \mathrm{ml}$ concentrated Nitric acid and $2 \mathrm{ml}$ concentrated Tetraoxosulphate (VI) acid. This was digested using Aluminum block digester 110 . The mixture was heated until white fumes evolved and a clear solution obtained. The essence of the digestion before analysis was to reduce organic matter interference and convert metals to a form that can be analyzed by Atomic Absorption Spectrometry. After digestion, samples were allowed to cool then transferred to $100 \mathrm{ml}$ volumetric flask. This was made up to the $100 \mathrm{ml}$ mark with distilled water and thoroughly mixed. The samples were centrifuged to separate insoluble materials. It was then filtered through 0.45 Millipore type filter, and the concentrated of the individual heavy metal was determined using Unicam 929 Atomic Absorption Spectrometer.

Quality Assurance: The equipment was first calibrated using buck certified atomic absorption standards for the respective trace metals to obtain calibration curves. Reagent blanks were first run at intervals of every ten sample analysis to eradicate equipment drift. All samples were analysed in duplicates for reproducibility, accuracy and precision.

Health Risk Assessment: The methods of Chanpiwat et al., (2014), Khan et al., (2013), Shah et al., (2010) WHO, 2008 and US EPA, (1989) were used to evaluate the potential health risks in this study. While the methods of WHO, (1996), US EPA, (1989) and US EPA, (2011) were used to evaluate the non-potential carcinogenic risk.

Metal Pollution Index (MPI): The metal pollution index (MPI) by Usero et al., (1997) was used to quantify the pollution status of the borehole water.

Classification Structure: The methods of Grimason et al., (2013) and Kempster et al., (1997) were used to classify the borehole water in this study.

\begin{tabular}{llll} 
& \multicolumn{3}{c}{ Table 1: Assumptions used in this study } \\
\hline Variables & Units & Values & References \\
\hline Ingestion rate (IR) & $\mathrm{mg} / \mathrm{kg}$ & 100 & US EPA, (1989) and US EPA (2010e) \\
Exposure Duration (ED) & Day/year & 70 & US EPA, (1989) and US EPA (2010e) \\
General body weight BW & $\mathrm{kg}$ & 70 & US EPA, (1989) and US EPA (2010e) \\
Exposure Frequency (EF) & Days/year & 365 & US EPA, (1989) and US EPA (2010e) \\
Average Time (AT) & Days/year & 25550 & US EPA, (1989) and US EPA (2010e) \\
& $\mathrm{Zn}$ & $3.00 E-01$ & US EPA, (2013), DEFRA, (2005) and WHO/FAO, (2013) \\
RFDos & $\mathrm{Cu}$ & $4.00 \mathrm{E}-02$ & US EPA, (2013), DEFRA, (2005) and WHO/FAO, (2013) \\
& $\mathrm{Mn}$ & $1.4 \mathrm{E}+01$ & US EPA, (2007) and US EPA, (2009a) \\
& & &
\end{tabular}

\section{RESULTS AND DISCUSSION}

Health Risk Quantification: The results of the potential health risk and non-carcinogenic risk is shown in Table 2. The average daily dosage (ADD) results showed low concentrations of the trace metals in the various borehole sites. Oluku 1 had Mn (0.04), Zn (0.11) and $\mathrm{Cu}(0.01)$ and Oluku 2 had Mn (0.43), Zn (0.18) and $\mathrm{Cu}$ (0.01). While Ikueniro $1 \mathrm{had} \mathrm{Mn}$ (0.05), Zn (0.17) and $\mathrm{Cu}(0.01)$ and Ikueniro 2 had $\mathrm{Mn}(0.04), \mathrm{Zn}(0.15)$ and $\mathrm{Cu}(0.01)$. This indicates that there might not be 
possible health risk via the daily ingestion of the borehole water. However, according to Singh et al., (2010), the level of toxicity of trace metals to humans depends upon their daily intake rate. Consequent of this, the dumpsite activities did not impact the water quality of the various boreholes. This might be that the distance between the dumpsite and the boreholes met the standard construction of boreholes $15 \mathrm{~m}$ ahead seepage points. In this study, the HQs were; Oluku 1 $\mathrm{Mn}(0.00), \mathrm{Zn}(0.00)$ and $\mathrm{Cu}(0.21)$ and Oluku $2[\mathrm{Mn}$ (0.03), $\mathrm{Zn}(0.01)$ and $\mathrm{Cu}(0.29)$. While Ikueniro 1 had $\mathrm{Mn}(0.00), \mathrm{Zn}(0.01)$ and $\mathrm{Cu}(0.32)$ and Ikueniro $2 \mathrm{had}$ $\mathrm{Mn}$ (0.00), $\mathrm{Zn}(0.01)$ and $\mathrm{Cu}(0.21)$.

Table 2: The results of the potential health risk, non-carcinogenic health risk and metal pollution index of borehole water collected from the vicinities of dumpsites in Nigeria

\begin{tabular}{|c|c|c|c|c|}
\hline & $\mathrm{mg} / \mathrm{L}$ & & & \\
\hline & Oluku 1 & ADD & RfD & HQ \\
\hline Mn & 0.03 & 0.04 & 14 & 0.00 \\
\hline $\mathrm{Zn}$ & 0.08 & 0.11 & 30 & 0.00 \\
\hline \multirow[t]{4}{*}{$\mathrm{Cu}$} & 0.01 & 0.01 & 0.04 & 0.21 \\
\hline & & & HI & 0.22 \\
\hline & & & MPI & $4.6 \mathrm{E}-06$ \\
\hline & Oluku 2 & ADD & $\mathrm{RFd}$ & HQ \\
\hline Mn & 0.30 & 0.43 & 14 & 0.03 \\
\hline $\mathrm{Zn}$ & 0.13 & 0.18 & 30 & 0.01 \\
\hline \multirow[t]{4}{*}{$\mathrm{Cu}$} & 0.01 & 0.01 & 0.04 & 0.29 \\
\hline & & & HI & 0.32 \\
\hline & & & MPI & $1.0 \mathrm{E}-04$ \\
\hline & Ikueniro 1 & ADD & $\mathrm{RFd}$ & HQ \\
\hline Mn & 0.04 & 0.05 & 14 & 0.00 \\
\hline $\mathrm{Zn}$ & 0.12 & 0.17 & 30 & 0.01 \\
\hline \multirow[t]{4}{*}{$\mathrm{Cu}$} & 0.01 & 0.01 & 0.04 & 0.32 \\
\hline & & & HI & 0.33 \\
\hline & & & MPI & $1.4 \mathrm{E}-05$ \\
\hline & Ikueniro 2 & ADD & RFd & HQ \\
\hline Mn & 0.03 & 0.04 & 14 & 0.00 \\
\hline $\mathrm{Zn}$ & 0.11 & 0.15 & 30 & 0.01 \\
\hline \multirow[t]{3}{*}{$\mathrm{Cu}$} & 0.01 & 0.01 & 0.04 & 0.21 \\
\hline & & & $\mathrm{HI}$ & 0.22 \\
\hline & & & MPI & $5.6 \mathrm{E}-06$ \\
\hline
\end{tabular}

NB: ADD; Average Daily Dosage, RfD; Reference Dosage, HQ; Hazard Quotient, HI; Hazard Index and MPI; Metal Pollution Index.

The non-cancer HQs of the three metals in various sites were far below the suggested HQ threshold of $>1$ (Chien et al., 2002; Wang et al., 2005; Huang et al., 2008). Thus signifying no direct significant adverse health impacts from the ingestion of the borehole water in all of the sampled sites. The HI of all the borehole sites also revealed low values [Oluku $1(0.22)$, Oluku 2 (0.32), Ikueniro $1(0.33)$ and Ikueniro $2(0.22)]$. This chronic health effects were < HI set by US EPA, (2009a) and Bortey-Sam et al., (2015). Thus an indication of non-carcinogenic impact if the borehole water were to be consumed.

Evaluation of The Metal Pollution Index (MPI): The results of the MPI obtained in this study are shown in Table 2. The revealed values are [Oluku 1 (4.6E-06), Oluku 2 (1.0E-04), Ikueniro 1 (1.4-05) and Ikueniro 2 (5.6E-06)]. These values were far lesser than the reference point value of $1 \mathrm{mg} / \mathrm{L}$ as described by Morillo et al., (2005). The observed MPI of these metals showed that their level in terms of concentrations were very low. This reflected that the dumpsites activities had no impact in the borehole water and no water quality deterioration was observed as at the time of this study.

Classification Evaluation of the Boreholes: In line with the structure suggested by Grimason et al., (2013) and Kempster et al., (1997) on the classification of drinking water quality (Table 3), all the borehole water fell within class 0 and I. In this study, only two trace metals were used to characterize the borehole water; $\mathrm{Mn}$ and $\mathrm{Zn}$. The range of values used to classify the water were $\mathrm{Mn}(0-0.05)$ and $\mathrm{Zn}(0-3.0)$ respectively (Figure 2). This study revealed that the water quality of all the examined borehole water were safe for drinking as at the time of this study. This finding is in consonance with the work of Grimason et al., (2013).

Table 3: Classification structures of the borehole water

\begin{tabular}{ccc}
\hline \multicolumn{3}{c}{$\mathrm{mg} / \mathrm{L}$} \\
\hline $\mathrm{Mn}$ & 0.03 & Class \\
$\mathrm{Zn}$ & 0.08 & 0 and I \\
& Oluku 2 & \\
$\mathrm{Mn}$ & 0.30 & \\
$\mathrm{Zn}$ & 0.13 & 0 and I \\
& Ikueniro 1 & \\
$\mathrm{Mn}$ & 0.04 & \\
$\mathrm{Zn}$ & 0.12 & 0 and I \\
& Ikueniro 2 & \\
$\mathrm{Mn}$ & 0.03 & \\
$\mathrm{Zn}$ & 0.11 & 0 and I \\
\hline
\end{tabular}

NB: Class 0; 'This is perfect water quality, good for lifetime usage, with no serious health impact on the consumer.' Class I 'Water in this class is non-toxic for lifetime usage, but within the ideal perfect water quality (Grimason et al., 2013; Kempster et al., 1997).

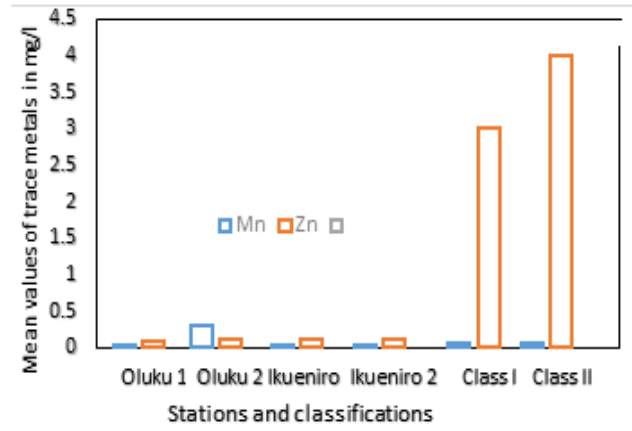

Fig 2: Classification structure of trace metals in the different borehole sites

Conclusion: The findings of this study have shown that the average daily dose (ADD) results indicated low concentrations of trace metals in the various borehole sites near dumpsites in Benin City. The hazard quotients and indices were less than 1 . Trace metals found in drinking water from the boreholes were within safe limits as referenced. On this premise, the borehole waters are recommended safe for consumption without potential health risk impact. 
Acknowledgements: We thank the Department of Environmental Management and Toxicology for giving us the platform in conducting this research work and the Ecotoxicology and Forensics Unit of University of Benin, Benin City, for assisting in the laboratory analysis of the samples.

\section{REFERENCES}

Achudume, AC (2009). The Effects of Petrochemical Effluent on the Water Quality of Ubeji Creek in Niger Delta Region. Bull. Environ.Toxicol. 83: $410-415$.

Adefemi SO (2013). Physicochemical and microbiological assessment of groundwater from Ijan-Ekiti South Western Nigeria. SWISS J. Appl. Sci. 2(5): 13-21.

Adegbola AA; Adewoye AO (2012). Impact assessment of selected pollution sources on groundwater quality in wells in Gambari Community, Ogbomoso, Nigeria. Int. J. Mod. Eng. Res. 2(5): 3118-3122.

Adeniyi A; Osifeko O; Owoade O; Omotayo Y; Ajede E; Ibrahim A; Balogun R (2014). Metal Burden as Template for Assessing the Quality of Raw Water Sourced from Two Rivers by Lagos State Water Corporation, Nigeria. In: Bhowon, M.G., Jhaumeer-Laullo, S., Wah, H.L. and Ramasami, P., Eds., Chemistry: The Key to our Sustainable Future, Springer, Dordrecht, 163-172.

Bortey-Sam N; Nakayama S; Ikenaka Y; Akoto O; Baidoo E; Yohannes YB; Mizukawa H; Ishizuka M (2015). Human health risks from metals and metalloid via consumption of food animals near gold mines in Tarkwa, Ghana: Estimation of the daily intakes and target hazard quotients (THQs). Eco-toxic. Environ. Safe. 111: 160-167.

Chanpiwat P; Lee B; Kim K; Sthiannopkao S (2014). Human Health Risk Assessment for Ingestion Exposure to Groundwater Contaminated by Naturally Occurring Mixtures of Toxic Heavy Metals in the Lao PDR. Environ. Monit. Assess. 186. 4905-4923.

Chien LC; Hung TC; Choang KY; Yeh CY; Meng PJ; Shieh MJ; Han BC (2002). Daily intake of TBT, $\mathrm{Cu}, \mathrm{Zn}, \mathrm{Cd}$ and As for fishermen in Taiwan. Sci. Tot. Env. 285: 177-185.

DEFRA, Environment Agency. Assessment of Risks to Human Health from Land Contamination: An Overview of the Development of Soil Guideline Values and Related Research, CLR7. DEFRA, Bristol, UK, 2005.

Grimason AM; Beattie TK; Morse TD; Masangwi SJ; Jabu GC; Taulo SC; Lungu KK (2013).
Classification and Quality of Groundwater Supplies in the Lower Shire Valley, MalawiPart 2: Classification of Borehole Water Supplies in Chikhwawa, Malawi. Water SA. 39: 573-581.

Huang ML; Zhou SL; Sun B; Zhao QG (2008). Heavy metals in vegetables: assessment of potential health risk for inhabitants in Khunshan China. Sci. Total. Environ. 405: 54-61.

Idris MA; Kolo BG; Garba ST; Waziri I (2013). Pharmaceutical industrial effluent: heavy metal contamination of surface water in Minna, Niger State, Nigeria. Bull Environ Pharm Life Sci. 2(3): 40-44.

Ija, U.J. and Antai S.P. (2003). Removal of Nigeria Light Crude Oil in Soil over 12 months period. Inter. Bio-deter. Bio-degrade. 51: 93-99.

Izah, SC; Chakrabarty N; Srivastav AL (2016). A Review on Heavy Metal Concentration in Potable Water Sources in Nigeria: Human Health Effects and Mitigating Measures. Expo Health DOI 10.1007/s12403-016-0195-9.

Kelepertzis E (2014) Investigating the sources and potential health risks of environmental contaminants in the soils and drinking waters from the rural clusters in Thiva area (Greece). Eco-toxic. Environ. Safe. 100: 258-265.

Kempster PL; Van Vliet HR; Kuhn A (1997). The Need for Guidelines to Bridge the Gap between Ideal Drinking-Water Quality and That Quality Which Is Practically Available and Acceptable. Water SA. 23: 163-167.

Khan K; Lu Y; Khan H; Zakir S; Khan S; Khan AA; Wei L; Wang T (2013). Health Risks Associated with Heavy Metals in the Drinking Water of Swat, Northern Pakistan. J. Environ. Sci. 25: 20032013.

Morillo J; Usero J; I Gracia (2005). Biomonitoring of trace metals in a mine-polluted estuarine system (Spain). Chemosphere 58: 1421-1430.

Musa JJ; Ahanonu JJ (2013). Quality assessment of shallow groundwater in some selected agrarian communities in Patigi Local Government Area, Nigeria. Int. J. Basic. Appl. Sci. 01(03):548-563.

Musa OK; Shaibu MM; Kudamnya EA (2013) Heavy metal concentration in groundwater around Obajana and Its environs, Kogi State, North Central Nigeria. Am. Int. J. Contemp. Res. 3(8):170-177. 
Shah MT; Begum S; Khan S (2010). Pedo and Biogeochemical Studies of Mafic and Ultramafic Rocks in the Mingora and Kabal Areas, Swat, Pakistan. Environ. Earth Scie. 60: 1091-1102.

Singh A; Sharma RK; Agrawal M; Marshall FM (2010). Risk assessment of heavy metal toxicity through contaminated vegetables from waste water irrigated area of Varanasi, India. Trop. Ecol. 51: 375-387.

Soyingbe AA; Salako SG; Hammed TB (2014). Sanitary Condition and Characteristics of Borehole Water Samples in Ogun State College of Health Technology, Ilese-Ijebu, Nigeria. African Journal of Medical and Health Sciences, 1: 57-63.

Ukpong EC; Okon BB (2013). Comparative analysis of public and private borehole water supply sources in Uruan Local Government Area of Akwa Ibom State. Int J Appl Sci Technol 3(1): 7691.

United States Environmental Protection Agency (USEPA) (1989). Risk Assessment Guidance for Superfund, Vol. 1: Human Health Evaluation Manual (Part A). EPA/540/1-89/002, Interim Final, Office of Emergency and Remedial Response, Washington DC.

United States Environmental Protection Agency (USEPA) (2011). Exposure Factors Handbook 2011 Edition (Final). United States Environmental Protection Agency, Washington DC.

US EPA (United States Environmental Protection Agency) (2009), Risk Assessment Guidance for Superfund (RAGS) Volume 1, Human Health Evaluation Manual (Part F), Supplemental Guidance for Inhalation Risk Assessment. EPA/540/R-070/002. Washington, D.C,
US EPA (US Environmental Protection Agency). IRIS, (Integrated Risk Information SystemDatabase). Philadelphia PA; Washington, DC, 2007.

US EPA (US Environmental Protection Agency) (2013). Reference dose (RfD): Description and use in health risk assessments, Background Document 1A, IRIS (Integrated risk information system). United States Environmental Protection Agency: Washington, DC, 15 March 2013

US EPA (US Environmental Protection Agency) (2010e).. The limits of pollutants in food. China: State Environmental Protection Administration, GB2762.

Usero J; González-Regalado E and Graccia I (1997). Trace Metals in the Bivalve Molluscs Ruditapes decussatus and Ruditapes philippinarum from the Atlantic Coast of Southern Spain. Environment International, 23: 291-298.

Wang X; Sato TB; Xing S (2005). Health risk of heavy metals to the general public in Tianjin, China via consumption of vegetables and fish, Sci. Total. Environ. 350 28-37.

WHO (1996). Guidelines for Drinking-Water Quality, Vol. 2: Health Criteria and Other Supporting Information. $2^{\text {nd }}$ Edition, World Health Organization, Geneva.

WHO (2008). Guidelines for Drinking-Water Quality. 3rd Edition, World Health Organization, Geneva.

WHO/FAO (2013). Guidelines for the Safe Use of Wastewater and food stuff; Wastewater Use in Agriculture, World Health Organization, Geneva 21(14) 988. 